\title{
The orthodox icon - means and mystical way of communion for juman beings with God through the Holy Spirit
}

\author{
Part III. The Icon that sanctifies the World
}

\section{Emanuel Sorin BUGNER*}

Abstract: The Orthodox icon is a reflection of divine reality. A deepening of our soul into the theology of Orthodox icons reveals a dimension that goes beyond the mundane. Influenced by this mystical presence of God, the icon gives us a personal encounter with the archetype of the image. In this encounter, we learn that the man, who truly enjoys real freedom, would only be a saint. The saints are the icons, our role models that tell us about true freedom and ask us for it. There is Jesus, whose sanctity hallows us all, so that all people can become living icons. Although God is hidden to us, he revealed himself as a human being in Jesus Christ, Him being the natural icon of His Father (Kol.1:15) who told us: "He, who has seen me, has seen the Father". Thus, those who want to encounter God, have to meet Jesus, and I meet Him when I encounter an icon (the image of God), my fellow human beings with love, freedom and mercy. The existence of the Orthodox icon is a real challenge for modern people and the whole post-modern world. Addressed by God, we should constantly ask ourselves how we stand before God's love or call. For some of us, the question remains unanswered: What makes us human? What keeps us in existence: the idols or the icon?

Keywords: Icon, Salvation, Holiness, Idol, Dogma, Prayer

${ }^{*}$ PhD, Priest at the Roman Orthodox Parish in Linz (Austria). 


\section{The Iconic Vocation of the Human Being}

Through creation, ontologically, the human being was built in the image of God (Genesis 1:26 to 27). Its face was a prefiguration of Christ to come, but Jesus Christ is not in the image but the very image of God, icon of the invisible Father (John 14:9; Colossians 1:15). The Heavenly Father gives himself a perfect image, hence becoming the eternal Archetype of the Son, who is His eternal natural icon, the perfect image of the Father, one with the Father. The Saving Logos also gives himself an image (an icon) by creating the human being, thus becoming its Archetype. The human being created in the image of God, ontologically akin to Him, is therefore His icon through imitation. If the human being is related to God through creation, the Embodiment of the Word represents the deification or the ontological recreation of the human being, which is objectively unified with God in Jesus Christ, the Embodiment of Logos, a god by grace, a living icon of its Archetype ${ }^{1}$.

The iconographer expresses in and through his work the inevitable momentum of his soul - otherwise hard to explain - to shape himself as a living icon, "humble transparency"2 of the light

${ }^{1}$ As an icon of God, the human face is also an anti-idol par excellence; therefore, self-worship or idolatry is against the image of God in human beings, an iconoclastic state. As an icon of His Father, Jesus fulfills the will of the One who sent Him into the world. Human beings, a creation of God the Logos, are meant to become an icon of Christ that is to resemble Him. The likeness as well as the ontological calling of human beings to salvation (Genesis 1:26) is the essential Christian vocation to contemplate the "image of His person", (Hebrew 1:3) to become the same image (2. Corinthians 3:18). The transfiguration of the Saviour is the crucial moment of revealing the possibility for human nature and the whole creation to transfigure into and through Christ.

${ }^{2}$ Olivier Clement, Preface, in Clement Romanul, Scrierile Părinţilor Apostolici, Bucharest: Institutul Biblic şi de Misiune al Bisericii Ortodoxe Române Publishing House, 1979, pp. 5, 72. The iconography is a work of God and has its origin in God, who created the human being in His image and likeness. 
of God's face, his Saviour. The idol-man, on the other hand, appears as a dark face, autonomous and atomized, his self-worship and the apparent openness of his image to the communion with others and with the whole creation proves to be unnatural in the end. The thirst of the postmodern person to self-reveal their own image is contrasting with the natural iconographic impulse of the faithful person, enlightened by the sacred mystery, whose image is part of the icon of Christ and who doesn't allow to be circumscribed by the artificial and blinding light of the artistic moment taking place on stage at any given time and place, where the idol-man doesn't show his face, but only his distorted and dismantled mask (the person). The contemplation of the image of the idol-man does not lift the mind to the glory of God and to the glow of the divine light, but stops at the created, opaque and fallen creature. This is actually the reason which prompted God to prohibit images in the Old Testament (Exodus 20:3 to 4; Psalm 96:7). It was meant as divine pedagogy, disregarded today by postmodern people, who places themselves, as visibly as possible, on the modernized pedestal of the golden calf from the Old Testament.

In case of the icon, but also of the idol-man, we are talking about matter. In the first case, the light comes from inside the archetype, the fountain of life and of deification. In the second, however, the poor and decomposed light of the sinful world is revealed as a sterile light, devoid of life. The icon shows the transfiguration of matter. The idol suggests its transformation. The theology of the icon refers to the transfiguration of the human being. While reductionist, idolatrous anthropology expresses the autonomous, anomic transformation of the human being, the icon calls for expression of divine beauty, for unity (John 17:21) and reality, expressing the concrete image of the eschatological reality and the divine future of the human being.

The saints are living icons through which God manifests Himself in silence. Idol-men are, regarding their incomplete 
ontological calling to achieve similarity, profane icons, lacking grace and transparency, through which that destructive diabolos noisily manifests itself, unscrupulously promoted by a part of postmodern mass media. The self-sufficient iconographic representation, although artistically brilliant, which does not point to the holy face, is an idol, because the idol, also applicable to celebrities or the so-called pop icons (VIPs), massively mediatised through printed or visual media, does not have a holy face to highlight and differentiate itself from. Instead, it keeps all the attention or veneration for itself and inside itself. Here, we can speak of the emergence of idolatry and self-worship. While contemporary celebrities enjoy their affirmation as idols, a designation that delights the ear of the secularised person and doesn't bother almost anybody anymore - even asking to be imitated, consolidating themselves on all social levels through the euphoric imitatio antichristi - the icon is a theophany of a sacred presence, whose otherworldly beauty sanctifies the world.

\section{The Saint as Living Icon through which the Light of Christ Shines}

Light of the world, Jesus Christ is the Saint par excellence, His holiness being the essential element of His nature. Although the attribute "holy" in its entirety can only be characteristic to Him, through our participation in His deification, the divine holiness is transmitted to us as well, because God wants the whole world to be filled with Saints. Thus, His holiness becomes perceivable, seen through his work and glorified all over the world. "Seek peace and holiness, without which no one shall see God" (Hebrews 1:14), the fountain of peace and holiness, the Saviour of the world attracting us into his holiness and deifying us through the work of the Holy Spirit 
in the Church $^{3}$. By filling us with holiness, the divine traits are imprinted into our own image, making it godlike.

Holiness, the culmination of human life that involves the indwelling of Christ within those who faithfully follow him, is not strict and individual, but, "a process of permanent Christian humanization through deification, taking place through the relationships between people and God, between people and the entire universe" 4 . This notion is indicating the state of genuine accomplishment, through the active power of Christ, the participation in the very life of God, the prevalence of spirit over matter. Holiness does not exclude the personal human effort, but it requires it. As such, the Saint is the new man who freed himself from all passions and in whom Christ dwells, the man who has chosen to sacrifice himself for his fellow human beings. His life motto is pro-existence. Reaching such a spiritual state, the Saint will be overwhelmed by the grace of God, the light of holiness in his soul reflecting outwards through his already "transparent" body.

The Saint, a fulfilled living icon, has entirely restored his humanity. To be more precise, this restoration of his own humanity is justified by his lack of triviality, incivility, dishonesty, passions and by the presence of the highest degree of sensibility, transparency, purity, modesty, the mystery of brotherhood $^{5}$, all these virtues being expressed to the same degree by the painted icon. Having Christ within himself, the Saint presents Him to all those surrounding him, because he "reveals God through human form, the humanised God"6, the One in

${ }^{3}$ Dumitru Radu, Indrumări misionare, Bucharest: Institutul Biblic şi de Misiune al Bisericii Ortodoxe Române Publishing House, 1986, p. 761.

4 Dumitru Stăniloae, Teologia Dogmatică Ortodoxă, vol I, Bucharest: Institutul Biblic și de Misiune al Bisericii Ortodoxe Române Publishing House, 1978, p. 275.

${ }^{5}$ Ibid., p. 264.

${ }^{6}$ Ibid., p. 272. 
whose image he was created. This indicates that both the painted icon and the Saint, the sanctified living icon, are matter filled by grace, sharing the same essential feature: they represent the means of communicating and emanating the love, righteousness and holiness of Christ, true ways through which the light of the Holy Spirit pervades.

\section{When God Dies, the Idol Appears}

"Being within the sacred" (M. Eliade). Human beings feel within themselves the religious tension for God, but idolatry tends to circumscribe the divine and to express it within the frames of immanence, so that the image of the idol-man closes any religious perspective within him and, instead of telling us about God, he reveals humanity's insufficiencies, which he is worshipping, unfortunately, oftentimes to fanaticism. The tragedy of the death of God is revealed by idolatrous contemporary people, by their disaggregated inner life and by the petrified, diseased, possessive and possessed world, in which they live and which has lost its essential connection with the higher, transcendent reality that the Orthodox icon has been revealing to us for more than two thousand years. The icon reveals the transfigured matter to the world and the man who has made his inner image visible, the holiness of Christ, from whom he took the image (Galatians 4:19), due to which he becomes a witness of the deification of the holy face, of the man, of the living icon, of the transfigured human body and of Christ himself.

Therefore, first comes the holy face and only then comes its icon. The holy face implies the icon and the icon does not exist without this face, which it implicitly indicates ${ }^{7}$. The Saint and

${ }^{7}$ Aristotle already asserted long ago, adding to the sayings of Plato, but also contradicting him, that ideas and the items they indicate exist simultaneously and are conditioning one another ("Der Begriff allein kann 
then his icon show us the One from which their face originates, making it possible to perceive the perfect circular, unitary and transcendent movement of the relationship between the icon and the original image. For the idol, the motion is relative, turbulent, spontaneous, centrifugal or centripetal, depending on its creator's emotions and personality, the movement of a relationship in which a meeting between time and eternity, between nature and divinity does not take place.

The concept of beauty in the case of self-worship and of profane art encounters difficulty in transmitting the divine revelation objectively, which artists oftentimes wish to express, unknowingly. The beauty of idolatrous art has value only through itself. It is subjective and belongs to a decomposed, selfish, levelled culture, noisily affirming its independence and freedom in contradiction with the liturgical beauty expressed through ascetical and contemplative prayer, able to release mankind from its carnal passions. For the modern artist, the current state of the world, meaning its decay and dehumanisation, appears to be normal. What he expresses through his art is actually his inner world, a demonic image which corrupts the mind with perverse imagery, portraying the human being as torn apart by passions and death ${ }^{8}$, a perverse imagery or a lustful fantasy. The spiritual

kein Einzelding dazu bringen zu existieren"). Plato would have said, that in every soul there already exists the knowledge about ideas, somewhat blurred, but by means of the memory, those apriori ideas would come to light ("In der Einzelseele ist das Wissen von Ideen bereits grundsätzlich angelegt, irgendwie verschüttet vorhanden, aber durch die Kraft der Wiedererinnerung werden die Ideen ans Licht gebracht"). See the commentary of Rad Ludwig, Philosophie für Anfänger von Sokrates bis Sartre, München, 2015, pp. 68-77.

8 Ioan Bizău, "Incursiuni în teologia şi arta icoanei", in Ce este icoana?, translated by Vasile Manea, Alba Iulia: Reîntregirea Publishing House, 2005, p. 116: "A spiritual death, which was consumed within the perverted ideologies of modernity and in the terrifying experiences of the large-scale 
vision, however, shows a refined type of voluptuousness that dominates the mind and soul of the living icon - fallen "from similarity", the iconic dimension of the divine creation being profoundly altered. Violence, perversions, mental fiction, contamination of life, religious and moral values becoming relative are just some of the ramifications of this fall.

The death of God appears in the context of the death of God's image ${ }^{9}$. In this fallen state, the beauty of God is no longer sought after, but the beauty of the human being is freed from moral and Christian rigour and subjugated by the trends of its times. This is how the idolatrous image appears, meant to be looked at without spiritual reasoning. Nowadays, art is made for art's sake, because there is nothing above the idol. Not even mankind.

\section{The Cult of the Own Image as Anti-iconic Manifestation of the Human Being}

By forgetting or ignoring the human body's ability to be sanctified, human beings fall from grace and become idols. Thus, the image of God disappears from their face and is replaced by their own image, which is disfigured, because the human corruptible body, the flesh and blood, are contrary to the world transfigured by the icon, an incorruptible and eternal world, which the carnal human being cannot inherit (1. Corinthians 15:50). Since ancient times, people have put emphasis on the appearance of their own bodies, creating patterns and setting standards regarding male and female beauty. For the Greeks, however, the genius of beauty did not emphasise eroticism, but it had a clear function: people had to be different from animals and

destruction of the living icons of God, as it happened in Nazi concentration camps, in the communist gulags and in all forms of totalitarianism that mutilated the face and the memory of humanity in the 20-th century".

${ }^{9}$ Ibid., p. 161. 
more similar to the gods. Beauty expressed what was good, healthy, perfect and ideal. There were no existential contradictions between gods and humans. The gods were humanized and humans were deified. Mankind's process of selfcreation was starting to take shape ${ }^{10}$.

The paradisiac condition of the first human beings has always inspired many artists, the naked bodies of the forefathers serving, even today, as perfect references for the imagination of everyone who only emphasises physical beauty, created in those times by divine hands. After the fall, people have created pieces of clothing, thus alleviating the feeling of shame because of their nakedness, a strong unnatural feeling that pushed down the altered iconic image like an unwritten law. Clothing, this second skin (die zweite Haut), as well as the unnatural feeling towards their own and their fellow human beings' nakedness has distinguished and still distinguishes people from animals ${ }^{11}$.

The desire to seek and express a pattern for the outer beauty of people is a strong inner feeling, which has always given birth to beauty trends, thus satisfying the innate human instinct to imitate,

${ }^{10}$ Norbert Borrmann, Frankenstein und die Zukunft der künstlichen Menschen, München: Dietrichs, 2001, p. 41. Fashionable clothing, even if it wasn't useful clothing (not used as protection against bad weather), evokes the feeling of power, distinction, originality, supremacy.

11 Ibid, p. 47: "Und, je mehr der Mensch Mensch wird, desto stärker ist er diesem Gesetz unterworfen: der Erwachsene mehr als das Kind, der Philosoph mehr als der Wilde. Anhänger der Freikörperkultur irren daher gewaltig, wenn sie ihre Nacktheit als Rückkehr zur Natürlicher postulieren". (The more a human becomes a human, the more he will be subjected to this law: the adult more than the child, the philosopher more than the savage. Thus, supporters of the naked body cult are utterly mistaken by viewing their nakedness as a return to their natural state). In reality, pure nakedness does not provoke sexual impulses, but if the body is covered with provocative undergarments (die zweite Haut), if it is painted, tattooed or embellished, it will result in its stimulation. 
to copy something or someone. This instinct is educated, shaped, directed and controlled, meaning it's undergoing a secularised educational process, which will teach people to dissimulate their inner feelings, to lie, to act. It's similar to a theatrical masquerade of people who imitate or copy without reason, because then we can no longer make a clear and healthy distinction between us and what or whom we have imitated, identifying ourselves with the original (unlike the icon), thus becoming our own idols, idolaters and self-worshippers. "God died" because we replaced Him. We expelled Him from our sphere of existence. This leads us to discover what we are not. Using the impropriated mask (the face), which veils and, at the same time, reveals the true, real being to us, we will receive magical powers and we will suffer a mutation of mentality, personality and behaviour, an unnatural external, artificial mutation, incompatible with eternity, with the everlasting time the icon tells us about ${ }^{12}$.

Alchemy does not ensure eternity. It is a mysterious science in which magic and chemistry, natural sciences and philosophy, are intertwined. According to its principles, some precious stones contain the mystery of God's presence, allowing them to give birth to ideas about a new creation of the world, on all its planes of existence. This way, it would be possible for people to be rejuvenated, diseases to be cured, ordinary metals to be transformed into gold etc. Alchemy was and is surrounded by a

${ }^{12}$ Early on, the human imagination created various scenarios and images (3000 BC in Mesopotamia, Egypt, India), revived today, contrasting with the saving holy images and the Christian beliefs about the real, eschatological meaning of human life. It's about the biological-genetic mutation in humans. Countless works of art depict the animal-man (Mischwesen), a monstrous creature, now present in movies, on television or, even more tragically, in certain cartoons for children. The machine-man, the humanoid or modern robot, are the heroes of our times and genetic engineering is booming. Ibid, pp. 56-60. 
mystical aura and was practiced in secret. Despite all of that, mentioning the role of human beings as alchemists, when preparing food, the well-known and analysed alchemist processes, sometimes manipulated, are found on a pro-creational level, when conception takes place, i.e. the merging of two elements of different types, which will result in a new life. It is the so-called chemical marriage, meaning that sexuality plays an important role in alchemy. The idea of artificial procreation as well as that of the human power to resurrect a dead being were already present in ancient mythical-alchemistic philosophy as proof of the imitation of the divine creational power by human beings on the one hand, but also of underestimating it, on the other hand ${ }^{13}$. It's no wonder that the Renaissance would implement the idea of the human being's omnipotence. Human beings can create better than God Himself does. He's the creator of a new human being, of the chemical human, of a mightier human being ${ }^{14}$. In everyday life of the new, artificially created human being, artificial intelligence (the electronic brain) plays a very dangerous role, and not just on an imaginary plane.

On the contrary, the tendency of human nature to represent invisible or intangible things in a perceivable way, derived from

${ }^{13}$ Ibid., pp. 62-73. Frankenstein himself is the living image of such alchemistic fantasies, but also the prototype for those who are to follow him. The doctor and philosopher Theophratus Bombastus von Hohenheim, also called Paracelsus (1493-1541), is known as the alchemist who owned the recipe for a man's birth in the absence of a natural mother, the so-called homunculus, mentioned long before him in ancient alchemy. In literature, this type of man, the homunculus, is mentioned in the work Faust by J. W. v. Goethe and immortalized on canvas by the artist Franz Stassen in 1916.

14 The word creation is used improperly in this context, for the material used by man to create embryos is already a living matter. Man only succeeds to replace the mother's womb with a test tube. This method not only renders the mother "unemployed", but allows the researcher to manipulate the further development of the embryo, thus of the human being. 
the human need to deal with concrete things, is identified and accepted by scholars as an iconological mentality. For example, Father Ene Branişte states that: "Man is inclined by nature to represent perceptively or in seen forms the unseen forms, or the things that cannot be sensed. The need to have an icon arises from the concreteness of the religious sentiment that cannot be satisfied with a mere spiritual contemplation and seeks to approach divinity directly. Man wants to see, to touch with his fingers, to kiss with his lips" 15 , the veneration of icons remaining "a living testimony of the human desire to deify through grace and a means of communication with God and his Saints, whose lives belong to human history" "16. Therefore, the icon offers the believer the possibility to contemplate the beauty of a spiritual world, having the power to lift the mind and soul to an immaterial plane, sanctifying them. Accompanying the word of the Gospel through images, the icon will surely lead us to the ultimate goal of any Christian: the endless sharing of divine grace.

The Holy Apostles have preached God's word. They confessed Whom they had seen with their own eyes, Whom they had listened to and Whom they had touched with their own hands. The Apostles could not contemplate Jesus as the Son of God by looking at Him, but through faith. Otherwise, he would have only been known as a historical figure, the son of Mary and Joseph, the carpenter. The words of God: "Who has seen me, has seen the Father." (John 14:9) were addressed to those who, by "watching the man Jesus, beheld His deification" 17 . The contemplation of the icon needs to be understood in the same

15 Ene Branişte, "Teologia icoanei", in "Studii Teologice', 2-nd Series, Year IV (1952), No. 3-4, p. 181.

${ }^{16}$ Nicolae Dură, "Teologia icoanei în lumina tradiţiei dogmatice şi canonice", in "Ortodoxia", Year XXXIV (1982), No. 1, p. 60.

17 Leonid Uspenski, Teologia icoanei, translated by Teodor Baconsky, Bucharest: Anastasia Publishing House, 1994, p. 117. 
way, since it doesn't simply represent the historical reality of the prototype, but it also unites "the historical reality and the grace of the Holy Spirit" 18 within itself. First of all, icons communicate the message of holiness to the world, showing us those who have achieved this goal and morally strengthening those who are pursuing it. By shaping and cleansing our souls, icons help us detach from the material world, from the weight of our sins, preparing our heart as "the saint of all saints"19. This is where the mysterious union of human beings with God takes place. This transformation of our entire being, once the heart has been cleansed, means the believer has reached a state of happiness by realizing the likeness of his original image. Thus, the human being, an icon darkened by sin, becomes pure, transparent, bright, housing divine grace, a centre of Christ's holiness, hence being able to conceive the One to whom he or she prays faithfully, because "all Saints conceive the Word of God in themselves, similarly to the Mother of God, and give birth to Him and He is born in them and they are born from Him"20.

Sanctified matter filled with grace ${ }^{21}$, from which the human soul drinks incessantly. The icon, the way through which, by ascending to God, we work on our likeness to Him, remains indeed a testimony of human desire for deification through honouring it. This fact has been recognized by the Saints participating in the Quinisext Council, held on the $1^{\text {st }}$ of September 692, in the hall of the Imperial Palace (in Trullo), as follows: "As the prophets have

${ }^{18}$ Ibid.

${ }^{19}$ Teoclit Dionisiatul, Dialoguri la Athos, vol. 1, translated by Ioan I. Ică jr., Alba Iulia: Deisis Publishing House, 1994, p. 31.

20 Sfântul Simeon Noul Teolog, "Cuvântări morale”, in „Filocalia”, vol. VI, translated by Dumitru Stăniloae, Bucharest: Institutul Biblic și de Misiune al Bisericii Ortodoxe Române Publishing House, 1977, p. 156.

${ }^{21}$ Christoph von Schönborn, Icoana lui Hristos, translated by Vasile Răducă, Bucharest: Anastasia Publishing House, 1996, p. 149. 
proclaimed, as the church has accepted, as the teachers have dogmatized, as the entire ecumenical Christianity has agreed upon, as grace has shone, as the truth has revealed itself, as lies have been banished, as wisdom has dared, as Christ overcame, so do we speak, so do we declare and honour Christ, our true God and His Saints with words, through writings, through thoughts, through sacrifice, through churches, through icons, attesting and honouring him as God and Lord and the others according to their relation. This is the faith of the Fathers, the Orthodox faith, this is the faith that has strengthened the world"22.

The human being was created as a free being. However, freedom is not a random gift, added to human nature after its creation, but it pertains to its existence. It represents an important part, through which the human being is able to cooperate with God. The refusal of this collaboration leads to the human mind living without light, therefore seeing everything deformed, seeing "people like walking trees" (Mark 8:24). The icon holds Life against death and Sanctity against moral decay, because "Jesus and His icon exist together",23. Praying in front of the icon and overseen by the Holy Spirit, we will also become living icons containing the light of Christ, like those who, honouring it with great faith, have died holding it in their arms.

\section{Conclusions}

Watched closely, the icon reveals and tells us, in a first phase, the truths of faith, being able to be compared to a true "Bible in Pictures", its educational role being clearly emphasised. As our gaze is purified of passions, the icon elevates us

${ }^{22}$ Ioan.I. Ică jr., "Sinodiconul Ortodoxiei”, in "Mitropolia Ardealului", Year XXX (1985), No. 7-8, p. 445.

${ }^{23}$ Teodor Studitul, apud. Dumitru Stăniloae, "Icoanele în cultul ortodox", in "Ortodoxia", Year XXX (1978), No. 3, p. 483. 
spiritually, until we can feel the presence of God's holiness in it. From this spiritual level, when the heart is cleansed of sin, we are overwhelmed by a different kind of knowledge of God: the direct and immediate knowledge of Him through our communion with Him in the Holy Spirit, a contemplative and mystical knowledge.

The sins that spring from a passionate heart always generate the alteration of religious and moral values in society, the seed of disbelief of the sinful human being continually growing, destroying their true hierarchy. This situation proves that the modern person ceases to feel the need for the sacred, for the communion with divinity, for maturity, for spiritual courage, and all this due to the loss of function of transcendent reality. Turned into an anti-iconic being, the post-Christian human being normalises an unnatural state as a basic rule for the development of his or her consciousness.

The physical, intellectual and moral libertinism of Nietzsche's "Übermensch", a maximum expression of his lack of moderation, is due to his moral decay, considered a high virtue, a demonological state opposed to an extreme extent to the perfect, iconological state, in which the martyrs of iconoclasm died with the icon in their hands. To be free means to continuously shape yourself "in the image and likeness of God" as a living icon, devoid of passion, remaining, after physical death, an icon-model for your descendants, who will honour you and hang your image above their forehead. Such a role model, overshadowed by the grace of the Holy Spirit, opposed to any ephemeral idol, saves, sanctifies and protects the life of the world and especially that of faithful people.

\section{References}

1. Bizău, Ioan, "Incursiuni în teologia şi arta icoanei", in Ce este icoana?, translated by Vasile Manea, Alba Iulia: Reîntregirea Publishing House, 2005. 
2. Borrmann, Norbert, Frankenstein und die Zukunft der künstlichen Menschen, München: Dietrichs, 2001.

3. Clement, Olivier, Preface in Clement Romanul, Scrierile Părinţilor Apostolici, Bucharest: Institutul Biblic și de Misiune al Bisericii Ortodoxe Române Publishing House, 1979.

4. Branişte, Ene, "Teologia icoanei", in "Studii Teologice", 2-nd Series, Year IV (1952), No. 3-4.

5. Dură, Nicolae, "Teologia icoanei în lumina tradiţiei dogmatice şi canonice”, in "Ortodoxia”, Year XXXIV (1982), No. 1.

6. Ică jr., Ioan I., "Sinodiconul Ortodoxiei", in "Mitropolia Ardealului", Year XXX (1985), No. 7-8.

7. Ludwig, Rad, Philosophie für Anfänger von Sokrates bis Sartre, München, 2015.

8. Radu, Dumitru, Indrumări misionare, Bucharest: Institutul Biblic şi de Misiune al Bisericii Ortodoxe Române Publishing House, 1986.

9. Rousseau, Daniel, Icoana. Lumina Feţei Tale, translated by Măriuca Alexandescu, Bucharest: Sophia Publishing House, 2004.

10. von Schönborn, Cristoph, Icoana lui Hristos, translated by Vasile Răducă, Bucharest: Anastasia Publishing House, 1996.

11. Sfântul Simeon Noul Teolog, "Cuvântări morale", in "Filocalia", vol. VI, translated by Dumitru Stăniloae, Bucharest: Institutul Biblic și de Misiune al Bisericii Ortodoxe Române Publishing House, 1977.

12. Stăniloae, Dumitru, Teologia Dogmatică Ortodoxă, vol. I, Bucharest: Institutul Biblic și de Misiune al Bisericii Ortodoxe Române Publishing House, 1978.

13. Uspenski, Leonid, Teologia icoanei, translated by Teodor Baconsky, Bucharest: Anastasia Publishing House, 1994. 